\title{
Are the Mechanisms for Assessing the Quality of Training for Graduates of the Russian Penitentiary System Perfect?
}

\section{¿Son perfectos los mecanismos para evaluar la calidad de la formación de los graduados del sistema penitenciario ruso?}

\author{
Nikolay V. Rumyantsev*' \\ Center of Studying of Problems of Management and the Organization Executions of \\ Punishments in Criminally-Executive System, Research Institute of the Federal Penitentiary \\ Service of Russia, Moscow, Russia. \\ ORCID: https://orcid.org/0000-0002-1170-8739

\section{Salikh Kh. Shamsunov} \\ Center of Studying of Problems of Management and the Organization Executions of \\ Punishments in Criminally-Executive System, Research Institute of the Federal Penitentiary \\ Service of Russia, Moscow, Russia. \\ ORCID: https://orcid.org/0000-0001-8804-1920

\section{Olga A. Bondareva} \\ Head of the Department of Methodological Support for Human Resources of the Central \\ Normative and Technical Laboratory, The Federal Penitentiary Service, Moscow, Russia. \\ ORCID: https://orcid.org/0000-0001-7636-2145
}

\section{*Correspondence}

Email: rumyantsevn.v@yandex.ru
Cite as:

Rumyantsev, N.V., Shamsunov, S. Kh., \& Bondareva, O.A. (2020). Are the Mechanisms for Assessing the Quality of Training for Graduates of the Russian Penitentiary System Perfect? Propósitos y Representaciones, 8 (SPE2), e800. Doi: http://dx.doi.org/10.20511/pyr2020.v8nSPE2.800 


\section{Summary}

The relevance of the study is due to the need to assess the quality of training of graduates of the Russian penitentiary system and the lack of an effective tool to assess the quality and level of training of graduates who have mastered professional educational programs at educational institutions of the Federal Penitentiary Service of Russia. In this regard, this article is aimed at identifying or disclosing mechanisms for evaluating the quality of educational services by independent experts, representatives of the employer, through professional and public accreditation of educational programs in educational institutions of the Federal Penitentiary Service of Russia. The leading methods to the study of this problem are general scientific methods (analysis, synthesis, analogy, generalization, etc.), which to introduce allow a comprehensive review of the procedure for professional and public accreditation of educational programs in the system of the Russian Federation. The article reveals the expected results of introducing the institution of professional public accreditation of educational programs in the Russian penitentiary system: improving the quality of the implemented educational programs, the level of organization of staff training, the quality and relevance of educational services, and the image of departmental services. The materials of the article are of practical value for improving the evaluation system of professional educational programs implemented in educational institutions of the Federal Penitentiary Service of Russia.

Keywords: educational policy, penitentiary system, professional and public accreditation, quality of education, stages of implementation.

\section{Resumen}

La relevancia del estudio se debe a la necesidad de evaluar la calidad de la formación de los egresados del sistema penitenciario ruso y a la falta de una herramienta eficaz para evaluar la calidad y el nivel de formación de los egresados que han dominado los programas educativos profesionales en educación. instituciones del Servicio Penitenciario Federal de Rusia. En este sentido, este artículo tiene como objetivo identificar o divulgar los mecanismos para evaluar la calidad de los servicios educativos por parte de expertos independientes, representantes del empleador, a través de la acreditación profesional y pública de programas educativos en instituciones educativas del Servicio Penitenciario Federal de Rusia. Los métodos principales para el estudio de este problema son los métodos científicos generales (análisis, síntesis, analogía, generalización, etc.), que introducir permiten una revisión integral del procedimiento para la acreditación profesional y pública de los programas educativos en el sistema del ruso. Federación. El artículo revela los resultados esperados de introducir la institución de acreditación pública profesional de programas educativos en el sistema penitenciario ruso: mejorar la calidad de los programas educativos implementados, el nivel de organización de la capacitación del personal, la calidad y relevancia de los servicios educativos y el imagen de servicios departamentales. Los materiales del artículo son de valor práctico para mejorar el sistema de evaluación de los programas educativos profesionales implementados en las instituciones educativas del Servicio Penitenciario Federal de Rusia.

Palabras clave: política educativa, sistema penitenciario, acreditación profesional y pública, calidad de la educación, etapas de implementación.

\section{Introduction}

In the Federal Law on Education accreditation is associated with checking the activities of an educational organization engaged in educational activities, the relevant criteria and requirements 
of Russian, foreign and international organizations, for compliance with educational standards (Senashenko \& Kuznetsova, 2010). Educational standards speak of three requirements: the learning result, the learning process, the material base of the educational organization. In the world of accreditation, from the Latin accredo, "trust", is associated with the trust to the quality of education, during the accreditation the assessment of the quality of graduates is main (Gendell, 2003). It is clear that in this case, first of all, employers are asked. However, since today more and more graduates do not work according to their specialty, they often ask the graduates about what they think about the quality of their education (Khan, 2001). And, of course, they ask the expert community. Thus, during the accreditation, a survey of employers, graduates and the expert community should be conducted. Expert community works with university documentation, according to clearly defined criteria of the accrediting organization (Szejner, 2009).

What is the problem of many authorities today: they switched to manual control and stopped attracting the professional community? More precisely, they themselves select experts, and far from always these experts are referential to the departmental professional community. The results of professional and public accreditation are considered during the state accreditation of educational organizations and form a rating of educational programs accredited by them.

According to the requirements of the time, the authors consider it appropriate to use the assessment of independent associations of experts and employers. In the world, these associations play a big role (The federal aimed program, 2011). There are currently over 40 accreditation agencies in 30 European countries (The Bologna Declaration, 2005). The quality control of education at the transnational level is carried out by the Global Alliance for Transnational Education (GATE).

The European system for the implementation of public accreditation in foreign universities is discussed in G. Augusti (2013) articles, B. Remaud (2013) and A.B. Zzöler et al. (2013).

There are such associations in Russia, and many of them conduct their accreditations. Given the analysis and the opinions of experts and scientists reflected in the collection of scientific papers "the development of a system of professional and public accreditation of educational programs in agricultural fields in the Russian Federation" and the experience in conducting professional and public accreditation showed that accrediting organizations and councils for professional qualifications in rocket engineering and space activities have been created; in the field of welding; in housing and communal services; in mechanical engineering; in the field of shipbuilding and marine engineering and other areas (Tempus PACAgro Project, 2017).

The National Council under the President of the Russian Federation for Professional Qualifications, created on the basis of the Order of the President of the Russian Federation (Decree of the President of the Russian Federation dated April 16, 2014 No. 249 "On the National Council under the President of the Russian Federation coordinates the work related to the procedures for professional and public accreditation in organizations on professional qualifications"). Assessing the quality and level of training of law enforcement officers who have mastered educational programs in departmental educational organizations through the procedure of professional and public accreditation requires, in our opinion, demands further development (Decree of the President, 2014).

\section{Methodological Framework}

It should be noted that by no means always accreditation, including public accreditation, takes place according to clear criteria and with the involvement of relevant specialized (departmental) 
experts. Therefore, instead of state accreditation, independent professional and public accreditation should be used by a joint decision of the authority and the trade community. More precisely, it is necessary to adopt regulations that describe under what conditions professionalpublic accreditation replaces state accreditation (The federal aimed program, 2016). Representatives of specialized structural divisions of institutions and bodies of the penal system of the Russian Federation could act as independent experts in the areas of training. What educational programs they accredit, and those organization exempt from state accreditation. That is, it is necessary to identify professional and social communities whose assessments could be the basis for exemption from state accreditation procedures.

The definition of occupational accreditation is indicated in the Part 4 of Article 96 of the Federal Law of December 29, 2012 No. 273-FZ "On education in the Russian Federation" “... professional and public accreditation of basic professional educational programs, basic professional training programs and (or) additional professional programs (further referred to as professional public accreditation - PPA) is a recognition of the quality and the level of training of graduates who have mastered educational programs in a specific organization, carrying out educational activities that meet the requirements of professional standards, labor market requirements for specialists, workers and employees of the appropriate profile" (Federal Law, 2012). According to the decree of the Government of the Russian Federation (2010), "the formation and maintenance of a list of organizations conducting professional and public accreditation of educational programs of higher education and (or) relevant additional professional programs are carried out by the Ministry of Science and Higher Education of the Russian Federation with the next publication of the list in the public domain on the official website of the Ministry science and higher education of the Russian Federation in the information and telecommunication network "Internet" (Decree of the Government, 2017).

Among the priority goals of the development of PPA can be identified: ensuring the quality of educational programs in accordance with federal state educational standards; maintaining a high level of institutional functioning; strengthening the service capabilities of educational organizations (Gedulyanova \& Gedulyanov, 2015).

In accordance with the aims and the tasks of conducting the PPA for educational organizations, the implementation of which will provide a solution to the problems of formation and assessment of the competitive advantages of educational organizations, are:

-monitoring and forecasting needs in the labor market of professional qualifications;

-inclusion in the register of AIS "Monitoring of professional and public accreditation";

-inclusion in the register of the National Council under the President of the Russian Federation for professional qualifications;

-receiving a full report, including recommendations for improving educational programs and confirming the quality of education;

-monitoring of the emergence of new professions, changes in labor functions, an independent assessment of the qualifications of a specialist in a departmental educational organization;

-institution prestige;

-attractiveness of departmental educational organization for future studens, consumers of educational services;

-international recognition of degrees awarded by a departmental educational organization;

-improving the quality of training for students and systematization of regulatory documents governing the activities of educational organizations in refraction of their type;

-passing the rating, monitoring of the organizations.

Analysis of the proposed solutions to the problems of formation and assessment of the competitive advantages of educational organizations shows that all the problems identified by us above cannot be solved at the level of one educational organization. 
M.V. Petropavlovsky, V.A. Smelik and O.G. Nefedova (2017) in the training manual "Professional and public accreditation in agricultural education: 'the Tempus PACAgro project model" indicates that the solution to the problem of developing professional and public accreditation, including the departmental educational organizations, consists in the mutual cooperation of the expert community and the creation of a monitoring system for analytical sections in the context of industries, professions, educational standards and other parameters; conducting multivariate data analysis in the context of the constituent entities of the Russian Federation, building a forecast for the development of the vocational qualification sphere.

In order to find optimal solutions to the problems of the Russian penitentiary system, first of all, one must rely on data on how it works now, on an analysis of the experience of training specialists in departmental educational organizations. However, it is helpful to understand what quality problems are, what problems with regard to the quality of education exist, what methods were used to solve them, which ones were successful and which were not.

\section{Results and Discussions}

Federal Penitentiary Administration Service Researcher of Russia together with the Criminal Code of the Federal Penitentiary Service of Russia in the framework of the Complex Plan of the Scientific Support of the Federal Penitentiary Service of Russia on 2018 conducted research on the justification and methodological support of professional and public accreditation of educational programs in the penal system of the Russian Federation (further - the PES). The studies found that the active introduction of the institution of professional and public accreditation in departmental educational organizations of the Federal Penitentiary Service of Russia will contribute to improving the quality of implemented educational programs, the level of organization of training the employees for penal executive system, the quality and demand of educational services and the image of the service in the PES.

What are the benefits for employers, for experts?

Today, in fact, many employers are looking less and less at a diploma and are increasingly paying attention to personal qualities, the background of a specialist who has come.

Let's consider the stages of the PPA, revealing a number of issues.

Analysis of the positions of regulatory of legal acts allows us to identify the main stages of verification:

-publication of an administrative document (order, directive);

-notification of the verifying institution (organization) about the verification;

-verification;

-making up an act of verification, the acquaintance of the head of the verified institution (organization) with it;

-preparation and approval of the report on the results of the verification;

-taking measures to eliminate identified discrepancies (if any are);

-control over the elimination of identified discrepancies (if any are).

The informing of the society and all interested parties about the accordance of accredited educational programs with the requirements of professional standards, labor market requirements for specialists, workers and employees of the corresponding profile is one of the most important tasks of professional and public accreditation. Therefore, the public presentation of the results of professional and public accreditation of educational programs is an integral element of the quality of educational services provided by educational organizations. 
The results of professional and public accreditation of educational programs are placed:

-on the sites of educational organization that have passed the procedure of professional and public accreditation of educational institutions in the form of a short report on the conducted PPA;

-on the websites of the Ministry of Science and Higher Education of the Russian Federation or the Ministry of Education of the Russian Federation;

-on the website of the National Council of the President of the Russian Federation on professional competencies;

-on the websites of civil society institutions (public associations, unions, associations and organizations) in the form of a brief report on the accreditation examination (PPA) as agreed.

The results of professional and public accreditation are used for the following purposes:

-informing the professional and scientific communities, students (parents and legal representatives of students), employers (associations of employers), the public and state institutions on the quality of educational services provided by educational organization;

-protect the interests of "end consumers" of basic professional educational programs, basic professional training programs and (or) additional professional programs, according to which educational organizations train students in order to guarantee the quality and required level of training;

-providing the educational organizations with a certificate (certificate) on the passage of professional public accreditation (PPA).

\section{Conclusion}

As an organization authorized to conduct professional public accreditation of basic professional educational programs, basic professional training programs and (or) additional professional programs in the penitentiary system of the Russian Federation, the Federal Penitentiary Administration Service Researcher Institute is determined. The necessary documents that regulate the procedure for conducting professional-public accreditation of educational programs in the penal system of the Russian Federation have been worked out.

Currently, the Federal Penitentiary Administration Service Researcher Institute is included in the list of the Ministry of Education and Science of Russia organizations authorized to conduct professional public accreditation of basic professional educational programs, basic professional training programs and (or) additional professional programs implemented in the interests of security and law and order in federal state educational institutions, subordinate to the Federal Penitentiary Service of Russia.

\section{Recommendations}

The organization and the conducting of professional and public accreditation of educational programs implemented in departmental educational organizations will contribute to improving the quality of implemented educational programs, improving the development and implementation of personnel policies in the penal system of the Russian Federation, and organizing training for employees of the penal system of the Russian Federation, as well as improving the image of the Russian penitentiary system.

In addition, the inclusion in the register of professional qualification boards empowered by the National Council will allow monitoring the current and future long-termneeds of institutions and bodies of the penal system and their professional education, updating qualification requirements (professional competencies) for filling positions in the penal system of the Russian Federation, as well as taking part in the examination of federal state educational standards of 
vocational education, exemplary basic professional educational programs and their projects, assessing their accordance with qualification requirements (professional standards), preparing proposals to improve the specified indicated standards of vocational training and educational programs.

\section{References}

Augusti, G. (2013). Origin, current status and development prospects of the European system of accreditation of engineering educational programs EUR-ACE. Engineering Education, $12,22-32$.

Decree of the Government. (2017). Decree of the Government of the Russian Federation of 04/11/2017 No. 431 "On the procedure for the formation and maintenance of a list of organizations conducting professional public accreditation of basic professional educational programs, basic professional training programs and (or) additional professional programs". Moscow: Government of the Russian Federation.

Decree of the President. (2014). Decree of the President of the Russian Federation of 04.16.2014 No. 249 "On the National Council of the President of the Russian Federation for Professional Qualifications". Moscow: Government of the Russian Federation.

Federal Law. (2012). Federal Law of December 29, 2012 No. 273-FZ On the Education in the Russian Federation". Moscow: Government of the Russian Federation.

Gedulyanova, N.S. \& Gedulyanov, M.T. (2015). The quality of education is the aim and the result of innovation. Eco-potential, 3(11), 46-49.

Gendell, A.L. (2003). Guidelines for the improvement of correction officer training in staffinmate relations: Doctoral Dissertation. Hartford: University of Hartford.

Government of the Russian Federation. (2010). Order of the Government of the Russian Federation of 10/14/2010 No. 1772-r "On the Concept of the development of the penal system of the Russian Federation until 2020". Moscow: Government of the Russian Federation.

Khan, E.W. (2001). Analysis of correctional officer training in the USA: Doctoral Dissertation. Oklahoma: Oklahoma State University.

Petropavlovsky, M.V., Smelik, V.A. \& Nefedova, O.G. (2017). Vocational Accreditation in Agricultural Education: Tempus PACAgro Project Model. Yoshkar-Ola: Mari State University.

Remaud, B. (2013). Competencies of graduates of engineering specialties: European perspectives. Engineering Education, 12, 12-22.

Senashenko, V.S. \& Kuznetsova, V.A. (2010). Education system and professional standards. University Management: Practice and analysis, 6, 33-37.

Szejner, R.T. (2009). Chief correctional officers' attitudes about prison education: impact upon prison education sustainability and recidivism rates: Doctoral Dissertation. Philadelphia: Saint Joseph's University.

Tempus PACAgro Project. (2017). Development of a system of professional public accreditation of educational programs in the agricultural sector in the Russian Federation. "Development of Public Accreditation of Agricultural Programs in Russia (PACAagro)" (543902-TEMPUS-1-2013-1-SK-TEMPUS-SMGR): Collection of scientific papers. St.Petersburg: FGBOU VO SPbG AU.

The Bologna Declaration. (2005). The Bologna Declaration adopted for implementation in the system of higher professional education of the Russian Federation by order of the Ministry of Education and Science of the Russian Federation of February 15, 2005 No. 40. URL: http://www.bologna.ntf.ru /p13aa1.html

The federal aimed program. (2011). The federal aimed program of the development of education for 2011-2015. URL: http://www.rg.ru/2011/03/09/obrazovanie-site-dok.html 
The federal aimed program. (2016). The federal aimed program of the development of education for 2016-2020. URL: http: //minobrnauki.rf/documents/5930/file/4787/FCPRO_na_2016-2020_gody.pdf

Zzöler, A.B., Erzil, M.Y., Payzen, A.E. \& Platin, B.E. (2013). Learning outcomes: the main element of accreditation of the educational program. Engineering Education, 12, 32-42. 